\title{
Isolation and characterization of Bacillus altitudinis JSCX-1 as a new potential biocontrol agent against Phytophthora sojae in soybean [Glycine max (L.) Merr.]
}

\author{
Xiaoxue Lu • Dongmei Zhou • Xi Chen • \\ Jinfeng Zhang $\cdot$ Huiwen Huang $\cdot$ Lihui Wei
}

Received: 29 October 2016 / Accepted: 26 January 2017 /Published online: 3 February 2017

(C) The Author(s) 2017. This article is published with open access at Springerlink.com

\begin{abstract}
Aims Phytophthora root and stem rot caused by the oomycete plant pathogen Phytophthora sojae (Kaufmann \& Gerdemann), is a destructive disease of soybean [Glycine $\max (\mathrm{L}$.) Merr.]. There is no straightforward available method to control this disease. The present study aimed to isolate a biocontrol agent (BCA) to control Phytophthora rot and gain insights into the mechanisms of biocontrol activity.

Methods Antagonistic bacteria screening, inoculation assays, histochemical and fluorometric stain-
\end{abstract}

Xiaoxue Lu and Dongmei Zhou contributed equally in this study.

Responsible Editor: Yoav Bashan.

Electronic supplementary material The online version of this article (doi:10.1007/s11104-017-3195-z) contains supplementary material, which is available to authorized users.

X. Lu • D. Zhou $\cdot$ X. Chen $\cdot$ J. Zhang $\cdot$ H. Huang $\cdot$

L. Wei $(\bowtie)$

Institute of Plant Protection, Jiangsu Academy of Agricultural

Sciences, Nanjing 210095, People's Republic of China

e-mail: weilihui@jaas.ac.cn

X. Lu $\cdot$ D. Zhou $\cdot$ X. Chen $\cdot$ J. Zhang $\cdot$ H. Huang $\cdot$ L. Wei

Key Laboratory of Food Quality and Safety of Jiangsu

Province-State Key Laboratory Breeding Base, Jiangsu Academy of Agricultural Sciences, Nanjing 210095, People's Republic of China ing and real-time polymerase chain reaction (RTPCR) were used to achieve the goals of the present study.

Results The results indicated that the isolated BCA strain JSCX-1 was characterized as Bacillus altitudinis. Further studies showed that JSCX-1 bacterial filtrate inhibited the mycelial growth and zoospore germination of $P$. sojae. Greenhouse experiments showed that biocontrol efficiency of JSCX-1 against $P$. sojae was $49.28 \pm 3.42 \%$. Our results revealed that JSCX-1 increased the reactive oxygen species (ROS) production and callose deposition of soybean leaves. Moreover, JSCX-1 upregulated the transcriptional level of the G. $\max$ PRla gene but not that of the LOX and ERF genes.

Conclusions $B$. altitudinis JSCX-1 can effectively reduce the infectivity of $P$. sojae via increasing the ROS production and callose deposition on soybean, and up-regulating the expression of salicylate-responsive gene GmPRla.

Keywords Phytophthora sojae - Bacillus altitudinis . Biocontrol $\cdot$ Induced resistance $\cdot$ Salicylic acid signaling pathway

\section{Abbreviations}

BCA Biocontrol agent

RT-PCR real-time polymerase chain reaction

ROS Reactive oxygen species 
ISR induced systemic resistance

SAR Systemic acquired resistance

\section{Introduction}

Phytophthora root and stem rot caused by the oomycete plant pathogen Phytophthora sojae (Kaufmann \& Gerdemann), is a destructive disease of soybean [Glycine $\max (\mathrm{L}$.$) Merr.], resulting in great yield reduc-$ tions and capital losses each year worldwide (Qiao et al. 2013). This disease can be controlled predominately through the incorporation of resistance genes (Anderson and Buzzell 1992; Shan et al. 2004; Song et al. 2013), applying fungicides, and using cultural practice to improve field drainage and soil tillage. Surveys on $P$. sojae indicated that it has a diversity of races and the races are apparently becoming more diverse and difficult to manage. The most effective way to combat the disease is by restricting the spread of the fungus and limiting its impact, however, unfortunately, there is no straightforward available method to achieve this.

Rhizospheres contain a plethora of microflora, and thus, it is probable that there are potentially effective microorganisms that act as biocontrol agents against both bacterial and fungal plant pathogens. These microbes are able to trigger induced systemic resistance (ISR) in plants against a broad range of pathogens (Van Loon and Bakker 2005; Van Wees et al. 2008) by activating a series of plant responses, including cellwall reinforcement (Benhamou et al. 1996), accumulation of defense-related enzymes (Benhamou and Belanger 1998), oxidative burst (Iriti et al. 2003), and secretion of secondary metabolites (Yedidia et al. 2003). Given the broad spectra and resistance levels that beneficial microbes induce, the application of a biocontrol agent (BCA) is considered a promising alternative way to control Phytophthora rot.

Among the various antagonists applied for the management of Phytophthora root and stem rot of soybean, the biocontrol agent Trichoderma brevicompactum and its volatile metabolites recently had been shown that can suppress the mycelial growth of $P$. sojae in vitro. Application of $T$. brevicompactum obviously reduced the disease severity of soybean caused by $P$. sojae in the greenhouse experiment (Ayoubi et al. 2012). Rhizobacteria such as Bacillus is one of the most common soil inhabitant, and widely used as antagonistic bacteria (Chen et al. 2007), studies showed that Bacillus pumilus had an excellent potential to be developed as BCA against $P$. sojae on soybean plant (Fu et al. 2011).

Bacillus is one of the most studied genera and has been shown to enhance plant growth, induce plant resistance, and confer abiotic stress (Thordal-Christensen et al. 1997; Pertot et al. 2013). Bacillus sp. can produce numerous antifungal compounds, such as lipopeptides (Ongena and Jacques 2008), bacillomycin (Chen et al. 2007), fengycin (Vanittanakom et al. 1986), surfactin (Thimon et al. 1992), and bacillibactin (Dertz et al. 2006). Thus, Bacillus has a broad spectrum of activity against multiple fungal pathogens. Lipopeptides extracted from Bacillus amyloliquefaciens CNU114001 inhibited the mycelial growth of six pathogenic fungi and the elongation of spore germ tubes ( $\mathrm{Ji}$ et al. 2013). In addition, Bacillus releases volatile compounds, belonging to alkyls, alcohols, esters, ketones, phenols and heterocyclics, to suppress the mycelial growth and the spore germination of fungal pathogens such as Fusarium oxysporum, Fusarium solani, Sclerotinia sclerotiorum and Botrytis cinerea (Fiddaman and Rossall 1994; Yuan et al. 2012; Li et al. 2014).

The elicitation of induced resistance by Bacillus and its metabolites has been demonstrated on a variety of crops to defend against pathogen attack in both greenhouse and field trails (Kloepper et al. 2004). Niu et al. (2011) found that Bacillus cereus AR156 induced hydrogen peroxide accumulation and callose deposition; moreover, it activated ISR in Arabidopsis through salicylic acid (SA)-and jasmonic acid (JA)/ethylene (ET)-dependent signaling pathways. Desoignies et al. (2013) investigated the impact of lipopeptides produced by Bacillus amylolequifaciens on the biocontrol of rhizomania disease caused by the fungus Polymyxa betae. Their results showed an effective ISR in sugar beet resulting in a significant reduction in $P$. betae infection. Additionally, Bacillus isolated from rainforest soil promoted plant growth and triggered ISR against the pathogenic bacterium Pseudomonas syringae pv. tomato DC3000 in Arabidopsis (Huang et al. 2015).

In the present study, we aimed to isolate $\mathrm{BCA}(\mathrm{s})$ against $P$. sojae from the rhizosphere soil of healthy soybean plants present in diseased field, and gain insights into the mechanisms of the disease control. The study included: (1) the isolation and screening of bacteria against $P$. sojae, (2) the evaluation of the biocontrol effects of selected BCA in the greenhouse, (3) the 
identification of the isolated BCA by $16 \mathrm{~S}$ rRNA and gyrB sequencing, physiological and morphological characteristics analyses, and (4) the investigation of the biocontrol mechanisms of the BCA strain by determining the inhibition of mycelial growth and zoospore germination in $P$. sojae, reactive oxygen species (ROS) production, callose deposition, and defense-related gene induction. In our study, we isolated a BCA strain $B$. altitudinis JSCX-1 and investigated the biocontrol efficiency of $B$. altitudinis JSCX-1 against Phytophthora root and stem rot of soybean caused by $P$. sojae, and gained insights into the mechanisms of biocontrol activity. Our study indicated that application of this BCA could be an available and promising method to control this disease.

\section{Materials and methods}

Tested fungi, plant lines and growth conditions

The $P$. sojae isolate P6497 (race 2) was provided by Professor Yuanchao Wang (Nanjing Agricultural University) (Song et al. 2013), and routinely grown and maintained on $10 \% \mathrm{~V} 8$ agar at $25^{\circ} \mathrm{C}$ in the dark (McLeod et al. 2008). P. sojae zoospores were obtained as described previously (Zhang et al. 2012). Soybean plants ('He Feng 35') were grown in a greenhouse at 20-23 ${ }^{\circ} \mathrm{C}$ (day) and $18-20^{\circ} \mathrm{C}$ (night) with $16 \mathrm{~h}$ of light, and leaves used for biocontrol experiments were obtained from 14-day-old plants. Soybean that was grown in the darkness at $20-23{ }^{\circ} \mathrm{C}$ for 3 days was used for etiolated seedlings. $\mathrm{R}_{2} \mathrm{~A}$ (Reasoner and Geldreich 1985) and Luria-Bertani (LB) (Bertani 1951) media were used to grow bacterial strains in this study.

Screening of antagonistic bacterial strains to P. sojae

Antagonistic bacteria were isolated from rhizosphere soils of soybean roots collected from soybean fields in Jiangsu province (N3412'33.24"; E119 03'31.45") in China. Suspensions with $10 \mathrm{~g}$ of soil samples and $90 \mathrm{~mL}$ of sodium chloride $(0.9 \%)$ were mixed in a shaker incubator at $30{ }^{\circ} \mathrm{C}$ for $15 \mathrm{~min}$, and diluted to $10^{-4}$. Then, $100 \mu \mathrm{L}$ of the dilution sample was placed on $\mathrm{R}_{2} \mathrm{~A}$ medium. After $24 \mathrm{~h}$, bacteria of different sizes and morphologies appeared on plates, and were individually isolated as single colonies and preserved in LB medium.
The screening of the antagonist activities of these isolated strains was carried out as follows: a small piece of $P$. sojae mycelial disk from the edge of a 5-day-old colony was transferred onto the center of a plate with $\mathrm{V} 8$ at $25{ }^{\circ} \mathrm{C}$ in the dark for $24 \mathrm{~h}$, and each isolated bacterium for triplicate in one plate was sown at a distance of $3 \mathrm{~cm}$ from $P$. sojae. Petri dishes were grown for an additional 7 days. The antagonism efficiency was equal to: $[(\mathrm{A}-\mathrm{B}) / \mathrm{A} \times 100]$, where ' $\mathrm{A}$ ' was the mycelial diameter of control, and ' $\mathrm{B}$ ' was the mycelial diameter of the fungus with the bacterial inoculation. Each treatment contained 3 plates and the experiment was repeated three times.

\section{Characterization and identification of antagonistic bacteria}

Physiological and morphological characteristics of the JSCX-1 strain were identified according to Bergey's Manual of Determinative Bacteriology. The tests included spore formation, gram staining, oxidase activity, catalase activity, gelatin liquefaction, starch hydrolysis and the citrate test. The genomic DNA of the strain JSCX-1 was extracted with Bacteria Genomic DNA Kit (CW Biotech, China). The 16S rRNA and gyrB gene sequences were amplified from the integrated chromosomal DNA of the isolate JSCX-1 using the universal primers 27F/1492R and UP-1S/UP-2Sr (Yamamoto and Harayama 1995; Galkiewicz and Kellogg 2008) (Table 1). The amplified fragments were sequenced by GenScript Co., Ltd. (Nanjing, China). The $16 \mathrm{~S}$ rRNA and $g y r B$ gene sequences were analyzed using BLAST network services at NCBI, and the genes with high similarities were selected as the references. Phylogenetic trees were constructed using MEGA version 5.1 (Tamura et al. 2011).

\section{Antagonistic effect experiments}

To test the antagonistic effects of JSCX-1 on the mycelia and zoospores of $P$. sojae in vitro, JSCX-1 was inoculated in $5 \mathrm{~mL}$ of $\mathrm{LB}$ in a shaker incubator at $30^{\circ} \mathrm{C}$ for $24 \mathrm{~h}$. Then, the culture filtrate was harvest and filtered using acrodisc syringe filter of $0.2 \mu \mathrm{m}$ Supor Membrane. Five mycelial disks of $12 \mathrm{~mm}$ diameter (from the edge of a 5-day-old colony) of $P$. sojae were placed in $10 \mathrm{~mL}$ of sterile cultural filtration or water in a plate at $25{ }^{\circ} \mathrm{C}$ for $24 \mathrm{~h}$. Zoospores $\left(1 \times 10^{4} / \mathrm{mL}\right)$ of $P$. sojae were mixed with the sterile cultural filtration 
Table 1 Primers used in this study

\begin{tabular}{|c|c|c|c|}
\hline Gene & Primer name & Primer sequences & Source \\
\hline 16S rRNA & $\begin{array}{l}27 \mathrm{~F} \\
1492 \mathrm{R}\end{array}$ & $\begin{array}{l}\text { 5'-AGAGTTTGATCCTGGCTCAG-3' } \\
\text { 5'-TACCTTGTTACGACTT-3' }\end{array}$ & Galkiewicz and Kellogg 2008 \\
\hline $\operatorname{gyr} B$ & $\begin{array}{l}\text { UP-1S } \\
\text { UP-2Sr }\end{array}$ & $\begin{array}{l}\text { 5'-GAAGTCATCATGACCGTTCTGCA-3' } \\
\text { 5'-AGCAGGGTACGGATGTGCGAGCC-3' }\end{array}$ & Yamamoto and Harayama 1995 \\
\hline GmPRla & $\begin{array}{l}\text { PR1a-RT-F } \\
\text { PR1a-RT-R }\end{array}$ & $\begin{array}{l}\text { 5'-GGGTGATGTTGCCTACGCTCAA-3', } \\
\text { 5'-CAGCAACCGTATCATCCCAAGC-3' }\end{array}$ & This study \\
\hline$G m L O X$ & $\begin{array}{l}\text { LOX-RT-F } \\
\text { LOX-RT-R }\end{array}$ & $\begin{array}{l}\text { 5'-TGGAGGTTTTAAGAGGAGATGG-3' } \\
\text { 5'-CCTGCGAGGGTAAGGATAGTTG-3' }\end{array}$ & This study \\
\hline GmEREBP & $\begin{array}{l}\text { EREBP-RT-F } \\
\text { EREBP-RT-R }\end{array}$ & $\begin{array}{l}\text { 5'-GATTACTCCCACATCGCTACCC-3' } \\
\text { 5'-AGATTCTTCCTCTGCCTCTTCA-3' }\end{array}$ & This study \\
\hline$E L F 1 B$ & $\begin{array}{l}\text { ELF1B-F } \\
\text { ELF1B-R }\end{array}$ & $\begin{array}{l}\text { 5'-CCACTGCTGAAGAAGATGATGATG-3' } \\
\text { 5'-AAGGACAGAAGACTTGCCACTC-3' }\end{array}$ & This study \\
\hline
\end{tabular}

or water at the volume ratio of $1: 1$ in a plate at $25^{\circ} \mathrm{C}$ for $24 \mathrm{~h}$. The mycelial growth and zoospore germination were observed under a light microscope by checking five randomly selected fields in each treatment.

To test the antagonistic effects of JSCX-1 in vivo, the experiments were performed on mature soybean leaves and etiolated seedlings (Dong et al. 2009). JSCX-1 was inoculated as above, soybean leaves and etiolated seedlings were fully submerged in cell suspensions of JSCX$1\left(\mathrm{OD}_{600}=1\right)$ or sterile water for $1 \mathrm{~min}$, then the center of a G. max leaf or etiolated seedling was infected with a small piece of $P$. sojae mycelial disk from the edge of a 5-day-old colony, mycelial-side down. The antagonistic effects of JSCX-1 were quantified by measuring the lesion lengths at $48 \mathrm{~h}$ post inoculation (hpi). Each treatment had 6 mature leaves or etiolated seedlings. The experiments were repeated three times.

Greenhouse pot bioassay

The biocontrol effects of JSCX-1 were evaluated by hypocotyl inoculation (Tyler et al. 1995) in a greenhouse. Soybean seeds were cultivated in vermiculite pots (vermiculite was sterilized 3 times by autoclaves for $121^{\circ} \mathrm{C}, 20 \mathrm{~min}$ ) and on the 10th day of development, each plant was suspended in $3 \mathrm{~mL}$ of JSCX-1 $\left(\mathrm{OD}_{600}=1\right)$ or sterile water. Three days later, the soybean hypocotyl was incised with a small wound and the wound was infected with a small piece of $P$. sojae mycelial disks from the edge of a 5-day-old colony. After 2 days, the disease incidence and biocontrol effects of JSCX-1 were evaluated. The disease incidence was equal to $\mathrm{A} / \mathrm{B} \times 100 \%$; where ' $\mathrm{A}$ ' was the dead plants and ' $\mathrm{B}$ ' was the total number of infected plants. The biocontrol effect was equal to: (disease incidence control-disease incidence treatment $/$ disease incidence control $\times 100 \%$. Each treatment had 15 soybean plants and the experiment was repeated three times.

Histochemical and fluorometric staining assays

Soybean leaves selected for the investigation of biocontrol mechanisms of JSCX-1 were treated as described above for the antagonistic effects assays. At 16 and 24 hpi with $P$. sojae mycelia, 6 mature leaves were collected for 3, 3'-diaminobenzidine (DAB) staining for ROS detection, and 6 mature leaves for aniline blue staining for callose detection, respectively. The methods of DAB and aniline blue staining were described previously (Thordal-Christensen et al. 1997; García-Andrade et al. 2011). ROS production was visualized as a reddish-brown precipitate in soybean leaves (Karimi et al. 2002), and callose deposition was observed and photographed under a ZEISS LSM 710 confocal microscope (ZEISS Microsystems).

\section{Transcriptional profiling analysis}

To test whether JSCX-1 could activate soybean plant defenses, we characterized GmPRla, GmLOX and GmEREBP defense gene expression during P. sojae infection in the presence or absence of JSCX-1 by quantitative real-time PCR. Soybean leaves were treated as in the antagonistic effects assays, and collected at 0 (uninfected by P. sojae), 6, 12, 24, and 48 hpi (Niu et al. 2011). The total RNA of leaves was extracted using 
TRIzol reagent (Invitrogen/Life Technologies, Paisley, UK). cDNA was synthesized using a PrimeScript RT reagent Kit with gDNA Eraser (Takara RR047A) following the manufacturer's instructions. SsoFast EvaGreen Supermix (Bio-Rad Corporation, USA) was used for these genes transcriptional analyses, the quantitative RT-PCR amplification was performed in the presence of EvaGreen Dye (Bio-Rad) with an iQ5 iCycler (Bio-Rad), and the thermal cycler conditions and reaction mixtures were carried out following the manufacturer's instructions.

The expression levels of the three genes were normalized to the ELF1B reference gene of soybean (Genbank accession no. NM_001249608.1). Primers were designed using Primer premier 5 (Premier corporation, Canada) and listed in Table 1. The Bio-Rad iQ5 Optical System Software (version 2.1) was used to analyze the threshold cycle $(\mathrm{Ct})$ value. The transcriptional levels of the three genes were determined in accordance with the function $\Delta \mathrm{Ct}=\mathrm{Ct}$ target gene $-\mathrm{Ct}$ reference gene, to compare untreated and treated expression levels, and $\Delta \Delta \mathrm{Ct}=\Delta \mathrm{Ct}$ treatment $-\Delta \mathrm{Ct}$ control, where the control was the $\mathrm{H}_{2} \mathrm{O}$-treated leaves. The induction ratio of treatment to control was calculated according to $2^{\wedge}(-\Delta \Delta \mathrm{Ct}$ ) (Livak and Schmittgen 2001). This experiment was repeated three times.

\section{Statistical analyses}

A one-way analysis of variance (ANOVA) was carried out followed with Duncan's new multiple range test $(P<0.05$, DPS 7.05$)$ to compare the difference in mycelium diameter of control and the treatments and GmLOX expression of different time intervals of each treatment. The $t$-test was conducted to compare the difference in zoospore germination, lesion length, disease incidence and genes expression of treatments and controls $(P<0.05$, SPSS 19.0).

\section{Results}

Screening and characterization of antagonistic bacteria

A total of 10 bacterial isolates isolated from soybean rhizosphere soil showed antagonistic activity to P. sojae.
Among these isolates, strain JSCX-1 had the strongest antifungal activity towards the growth of $P$. sojae in in vitro assays compared with the other strains (Fig. S1). The growth inhibition ratio of JSCX-1 to $P$. sojae reached $63.94 \pm 3.94 \%$ at 7 days post confrontation (Fig. 1).

The physiological and morphological characteristics of the strain JSCX-1 were analyzed (Table S1). JSCX-1 exhibited positive results in most of the tests, such as spore formation, gram staining, oxidase activity, catalase activity, gelatin liquefaction, starch hydrolysis and the citrate test, indicating that JSCX-1 belonged to the genus Bacillus. Further studies based on 16S rRNA (GenBank accession no. KU955326) and gyrB gene (GenBank accession no. KU955327) sequencing and the phylogenetic analysis identified JSCX1 as Bacillus altitudinis (Fig. S2; Fig. 2).

Inhibition effects of bacterial filtration on the mycelial growth and zoospore germination of $P$. sojae

The suppression of bacterial filtration on $P$. sojae mycelial growth and zoospore germination was evaluated under a light microscope (Fig. 3). P. sojae mycelia had a disorganized development, highly vesiculated protoplasm and fewer branches in the cell free culture filtrate of B. altitudinis JSCX-1 (Fig. 3a). In contrast, the $\mathrm{H}_{2} \mathrm{O}$ treated $P$. sojae mycelia exhibited regular development, typical protoplasm, and rectangular branching (Fig. 3a). Furthermore, the zoospore germination of $P$. sojae was strongly inhibited by the culture filtrate of strain JSCX1 , with an inhibition of $42.50 \pm 1.56 \%$, in comparison with $\mathrm{H}_{2} \mathrm{O}$-treated control (Fig. $3 \mathrm{~b}$ and c).

BCA effects of JSCX-1 on P. sojae in soybean leaves and etiolated seedlings

The antagonistic effects of JSCX-1 against $P$. sojae in soybean leaves and etiolated seedlings were investigated. Two days after $P$. sojae infection, $\mathrm{H}_{2} \mathrm{O}$-treated leaves showed extensive lesion (Fig. 4a). However, applications of JSCX-1-treated leaves exhibited a significant reduction in lesion length compared with the control at 48 hpi (Fig. 4a), with the control effect being $61.11 \pm 3.29 \%$ (Fig. 4c). Similarly, JSCX-1 dramatically protected against the infection of $P$. sojae in soybean etiolated seedlings at 48 hpi (Fig. 4b), with an efficiency of $75.94 \pm 4.55 \%$ (Fig. $4 d$ ). 
Fig. 1 Inhibition effect of JSCX-

1 on the mycelial growth of

P. sojae at 7 days post

confrontation. P. sojae in the presence of strain JSCX-1 (a), and $P$. sojae alone (b). The experiment was repeated three times with similar results
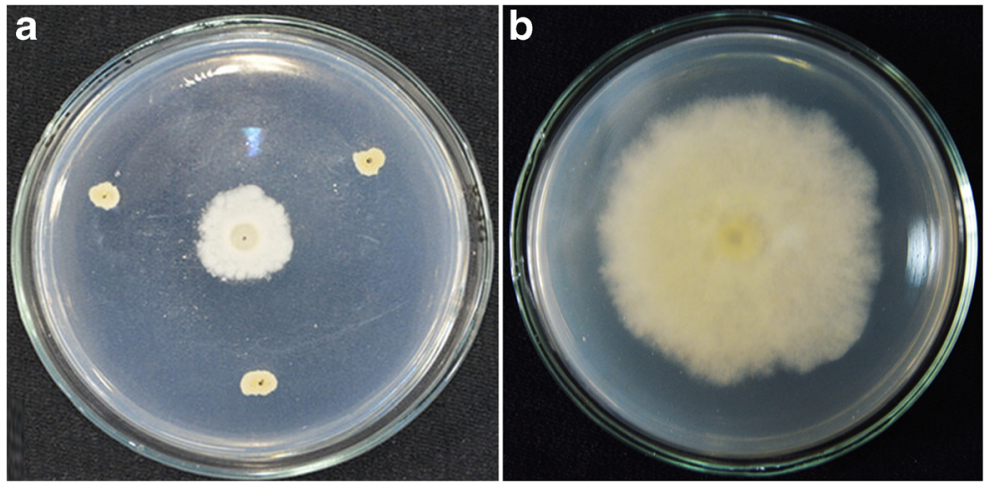

Biological control of JSCX-1 against $P$. sojae in soybean plants

Hypocotyl inoculation assay was performed to evaluate the biocontrol activities of JSCX-1 against $P$. sojae in soybean. Two day after $P$. sojae inoculation, the $\mathrm{H}_{2} \mathrm{O}$-treated plant showed representative phenotypes with leaves drooping and wilting and had reached the disease incidence up to $80 \%$. Soybean plants pretreated with a cell suspension of $B$. altitudinis had an obvious decrease in disease incidence when compared with

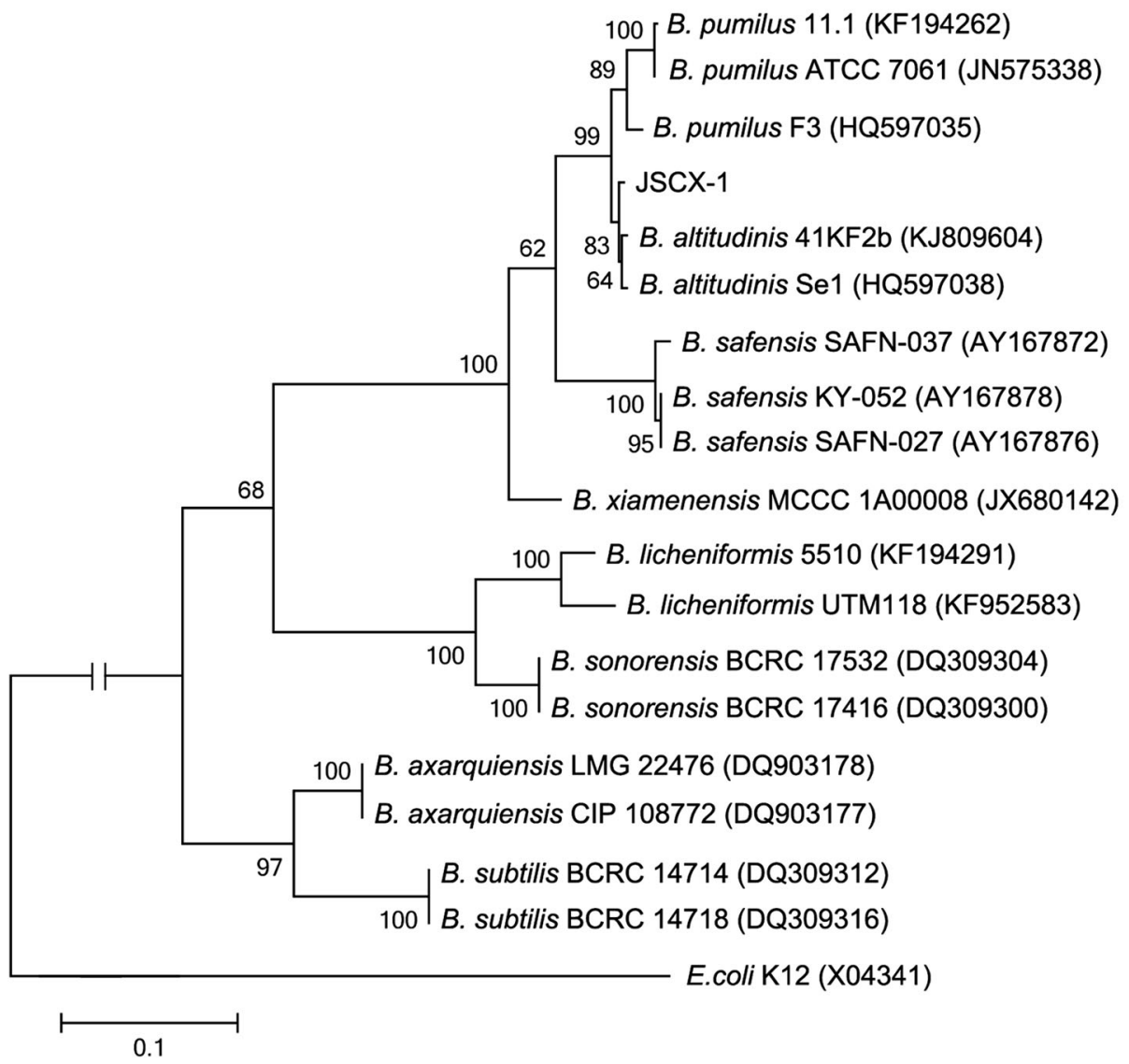

Bacillus

Escherichia

Fig. 2 Neighbor-joining phylogenetic trees based on gyrB gene sequence, showing the position of strain JSCX-1 among other members of the genus. Numbers at nodes are percentages that indicate the bootstrap values (expressed as 1000 replications). The scale bar $=0.1 \mathrm{nt}$ substitutions per site 

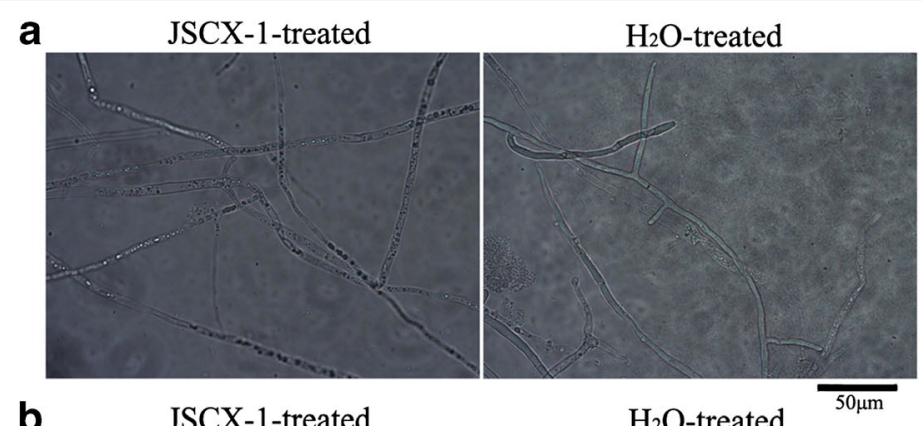

\section{C}
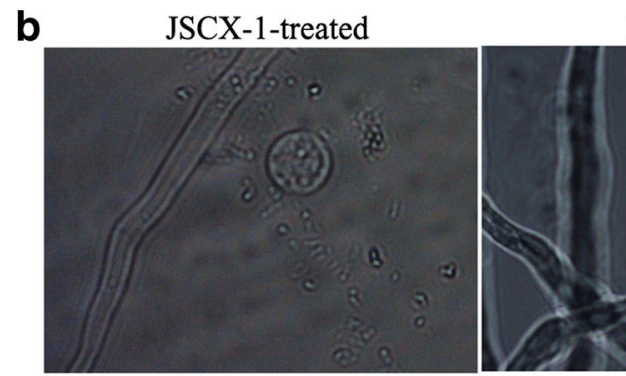

$\mathrm{H}_{2} \mathrm{O}$-treated

Fig. 3 The strain JSCX-1 suppressed $P$. sojae mycelial growth and zoospore germination. a Abnormal changes in $P$. sojae mycelia were observed following treatments with JSCX-1 for $24 \mathrm{~h}$ compared to $\mathrm{H}_{2} \mathrm{O}$-treated control, as observed under a light microscopy. Bar $=50 \mu \mathrm{m}$. b Fewer $P$. sojae zoospores germinated in the presence of the JSCX-1 filtrate after $24 \mathrm{~h}$ compared to $\mathrm{H}_{2} \mathrm{O}$ -

the $\mathrm{H}_{2} \mathrm{O}$-treated control (Fig. 5a) at an efficiency of $49.28 \pm 3.42 \%$ (Fig. $5 b$ ).

The antagonistic bacteria JSCX-1 activates soybean plant defense responses

To assess whether JSCX-1 could activate soybean defense responses, ROS production and callose deposition in soybean were evaluated (Fig. 6). Treatment of leaves with cell suspensions of JSCX-1 led to an increase in ROS production (Fig. 6a) and callose deposition (Fig. 6b) in soybean leaves at 16 hpi and 24 hpi when compared with the $\mathrm{H}_{2} \mathrm{O}$-treated control.

The relative expression levels of the SAresponsive gene GmPRla (Van Loon and Van Strien 1999), JA-responsive gene GmLOX (Wang et al. 2000), and ET-responsive gene GmEREBP (Lorenzo et al. 2003) were further measured at various time points of infection to validate that JSCX-1 could induce soybean systemic resistance possibly through a single defense pathway. Transcriptional levels of the three genes were evaluated after $P$. sojae infection at $0,6,12,24$, and

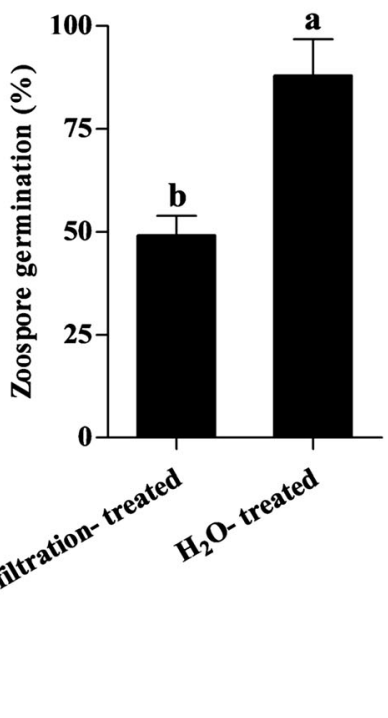

treated control, as observed under light microscopy. Bar $=10 \mu \mathrm{m}$. c Inhibitory effects of the JSCX-1 filtrate on $P$. sojae zoospore germination compared with the control. Data are means $\pm \mathrm{SE}$, where $\mathrm{SE}=\mathrm{SD} /$ sqrt (n) and $n=5$. Different lowercase letters above the bars indicate significant differences among the treatments at the $P<0.05$ level as indicated by $t$-test

48 hpi. The transcriptional level of GmPRla in JSCX-1-pretreated leaves appeared significantly faster and stronger at 0,6 , and 12 hpi than those of the $\mathrm{H}_{2} \mathrm{O}$-treated control leaves. In contrast, the transcriptional level of $G m L O X$ was reduced at 6 and 12 hpi by $P$. sojae in $\mathrm{H}_{2} \mathrm{O}$ - and JSCX-1treatments when comparing to those at $0 \mathrm{hpi}$. However, the ET-responsive gene GmEREBP was constantly expressed at a steady level and did not show any differences in the $\mathrm{H}_{2} \mathrm{O}$-treated and JSCX-1-treated leaves (Fig. 6c).

\section{Discussion}

Phytophthora rot occurs in soybean worldwide and is difficult to manage. Studies on the use of BCA to control this disease are limited. In the current study, we isolated a bacterial strain, JSCX-1, from the rhizosphere soil of healthy soybean from disease fields with biocontrol abilities to $P$. sojae infection. This bacterial strain JSCX-1 was identified as B. altitudinis and found to induce resistance to $P$. sojae in soybean by significantly reducing $P$. sojae infections. 
a

JSCX-1-treated
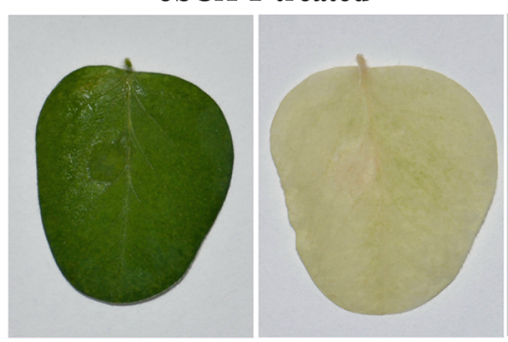

b

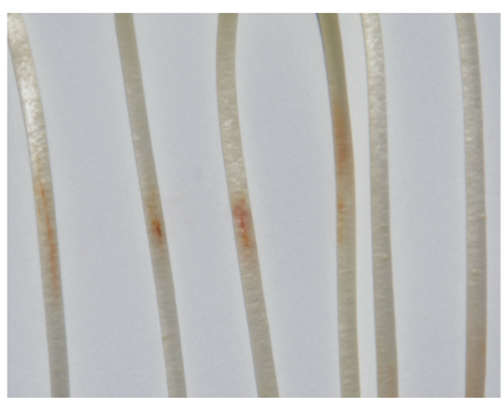

$\mathrm{H}_{2} \mathrm{O}$-treated

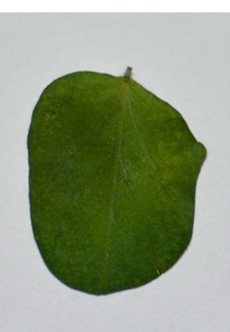

$\mathrm{H}_{2} \mathrm{O}$-treated

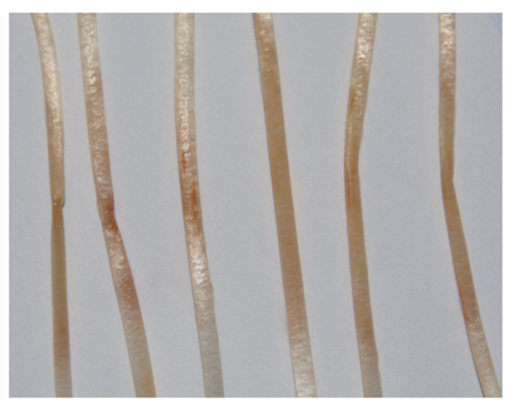

\section{2.4}
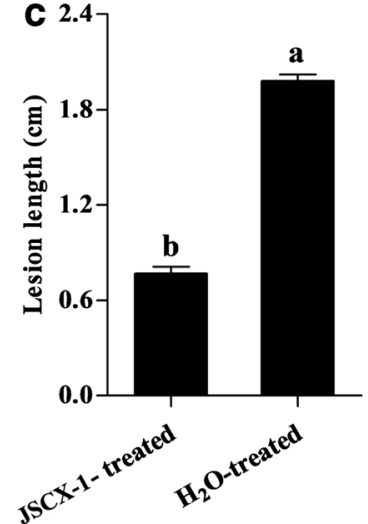

d $6_{7} \quad$ a

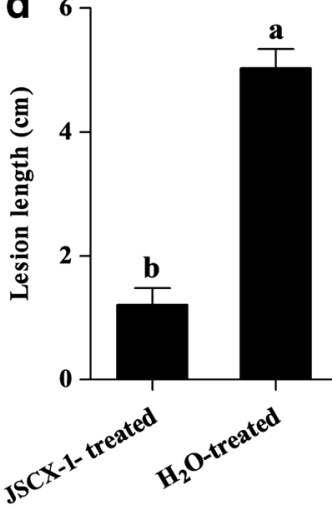

Fig. 4 Pretreatment with JSCX-1 enhanced the resistance of soybean to $P$. sojae. (a and b) Soybean leaves and etiolated seedlings upon $P$. sojae infection. The lesion lengths were measured at 48 hpi. (c and d) Biocontrol efficiency of JSCX-1 against $P$. sojae in soybean leaves and etiolated seedlings. The experiments were repeated three times with similar results, and the figures represented one of the results. Data are means $\pm \mathrm{SE}$ where $\mathrm{SE}=\mathrm{SD} /$ sqrt (n) and $n=6$. Different lowercase letters above the bars indicate significant differences among the treatments at the $P<0.05$ level as indicated by $t$-test a

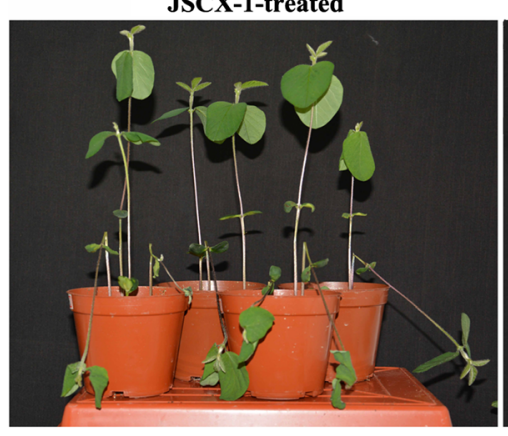

$\mathrm{H}_{2} \mathrm{O}$-treated

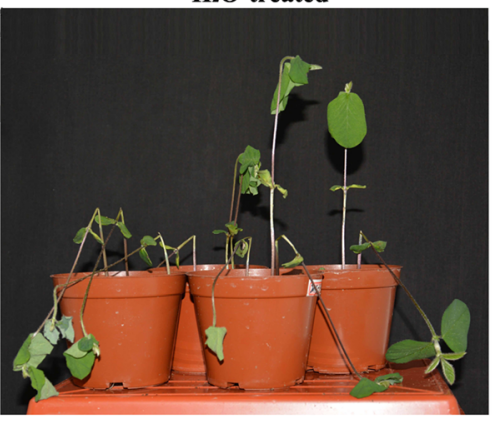

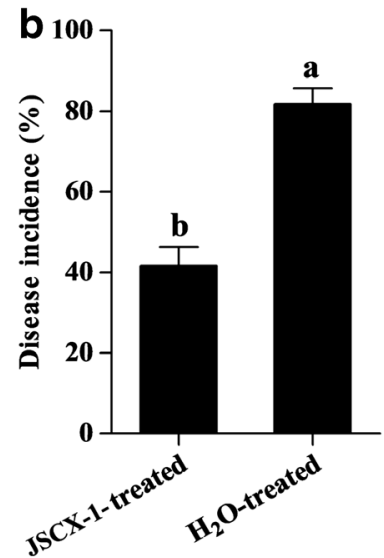

repeated three times with similar results. Data are mean $\pm \mathrm{SE}$ from 15 plants each from three independent experiments, $\mathrm{SE}=\mathrm{SD} / \mathrm{sqrt}$ (n) and $n=3$. Different lowercase letters above the bars indicate significant difference between the treatments at $P<0.05$ level by $t-$ test 

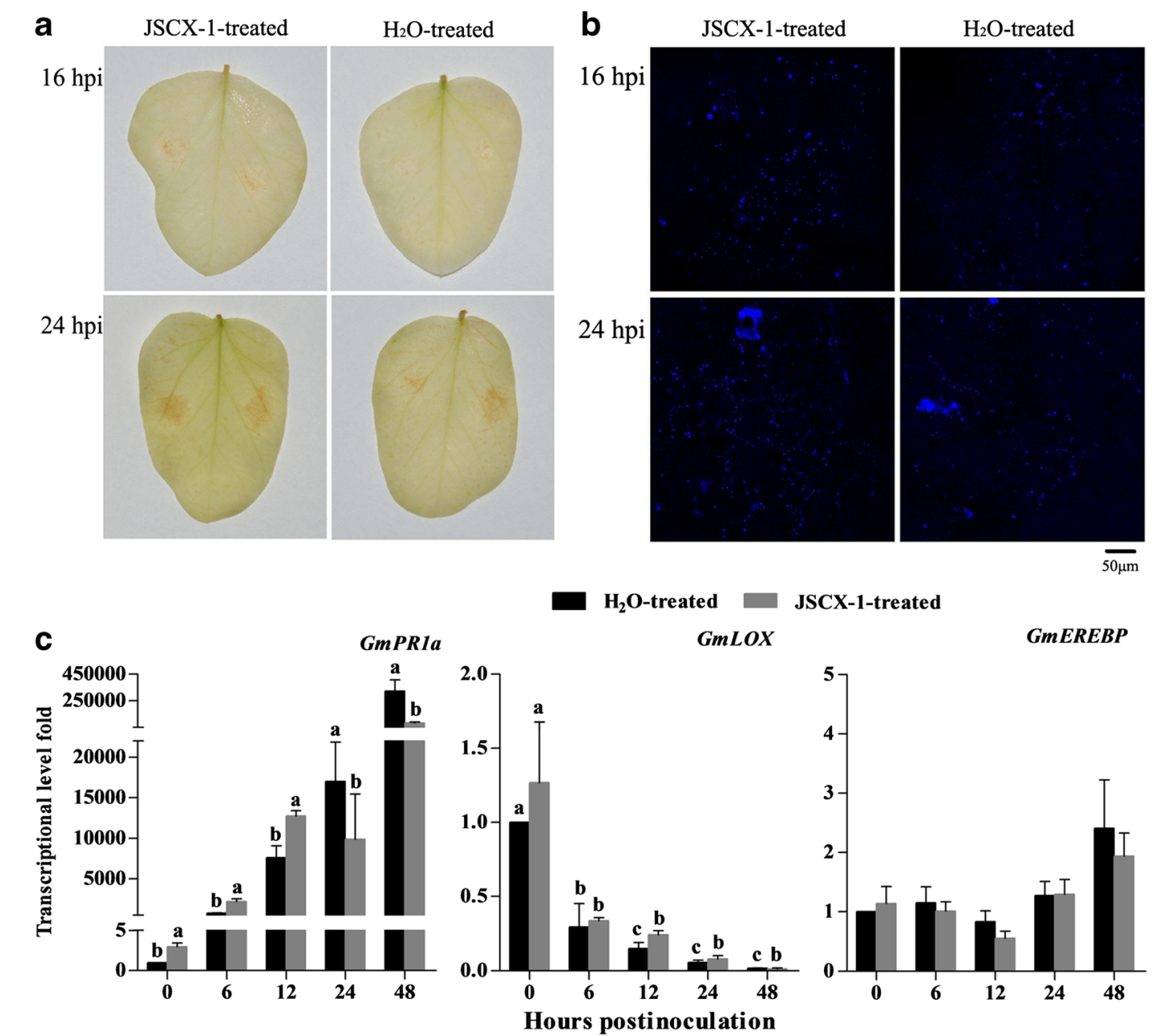

Fig. 6 JSCX-1 increased ROS production, callose deposition and expression of GmPRla in soybean leaves. a ROS production and b callose deposition after $P$. sojae infection of soybean leaves. $\mathrm{DAB}$ (for ROS production) and aniline blue staining (for callose deposition) were performed at $16 \mathrm{hpi}$ and $24 \mathrm{hpi}$, respectively, in JSCX-1- and $\mathrm{H}_{2} \mathrm{O}$-treated soybean leaves. Bar $=50 \mu \mathrm{m}$. c JSCX-1 up-regulated the transcriptional level of G. max PRIa. Transcript levels of the GmPR1a, GmLOX and GmEREBP genes in JSCX-1treated soybean leaves compared with the $\mathrm{H}_{2} \mathrm{O}$-treated control after $P$. sojae infection at different time intervals, measured by qRT-PCR. The experiment was repeated three times with similar

Many studies reported that the application of Bacillus spp., such as B. subtilis, B. cereus, Bacillus licheniformis, could manage diseases caused by Phytophthora species, such as Phytophthora capsici, P. sojae, Phytophthora fragariae var. fragariae, Phytophthora infestans, and Phytophthora cactorum on pepper, soybean, potato, cucumber, alfalfa, strawberry and apple (Utkhede 1984; Handelsman et al. 1990; Osburn et al. 1995; Anandhakumar and Zeller 2008; results. Error bars represent standard errors from three independent RNA isolations and qRT-PCR replicates. Lowercase letters above the bars indicate significant differences between the $\mathrm{H}_{2} \mathrm{O}$-treated control and JSCX-1-treated soybean leaves at $P<0.05$ level by $t$ test (left of Fig. 6c). Different lowercase letters above the bars indicate significant difference of different time intervals of each treatment at $P<0.05$ level by Duncan's new multiple range test (middle of Fig. 6c). No significant differences of GmEREBP expression were found between the $\mathrm{H}_{2} \mathrm{O}$-treated control and JSCX-1-treated soybean leaves (right of Fig. 6c)

Özyilmaz and Benlioglu 2013; Maksimov et al. 2014; Khabbaz et al. 2015).

Biocontrol agents against $P$. sojae that have shown effectiveness in disease reduction include several Bacillus (Osburn et al. 1995), Trichoderma (Ayoubi et al. 2012), and Actinomycetes (Filonow and Lockwood 1985). Fu et al. (2011) found that B. pumilus B048 could suppress the occurrence of $P$. sojae on soybean plant. Application of 
T. brevicompactum to soybean seeds was an effective strategy for management of damping-off, disease seveirity as well as increasing growth of treated seeds (Ayoubi et al. 2012). Streptomyces isolate GS93-96 reduced the percentage of dead plant caused by $P$. sojae under low pathogen inoculum, with the biocontrol efficiency of $80 \%$ (Xiao et al. 2002). However, under high pathogen inoculum, the same pathogen inoculum with in this study, application of Streptomyces GS93-96 could not reduce the percentage of dead plant (Xiao et al. 2002).

In the present study, the bacterial strain JSCX-1 belonging to $B$. altitudinis showed significant antagonistic activity to $P$. sojae with an inhibition ratio of $63.94 \pm 3.94 \%$ (Fig. 1). Recently, reports of $B$. altitudinis having the ability to promote growth and suppress root fungal pathogens, such as Macrophomina phaseolina and Thanatephorus cucumeris, were described (Gopalakrishnan et al. 2011; Sunar et al. 2015), indicating that B. altitudinis was a promising BCA for controlling fungal diseases. In our study, B. altitudinis JSCX-1 showed significant biocontrol activity in in vivo and in vitro assays (Figs. 4 and 5), suggesting that $B$. altitudinis JSCX-1 is a new BCA against $P$. sojae. Notably, this is the first report that B. altitudinis is able to control Phytophthora rot disease.

$B$. altitudinis has been recently characterized as a new causative agent of bacterial soft rot on apple and pear fruit (Elbanna et al. 2014). Accordingly, we tested whether the $B$. altitudinis JSCX-1 isolated in this study could cause soft rot on these fruit. We did not observe the soft rot disease symptoms as reported on apple and pear fruit (data not shown). This illustrated that $B$. altitudinis JSCX-1 is not a pathogenic agent of the bacterial soft rot.

The production of antifungal compounds is an important way in which BCAs from Bacillus spp. defend against pathogens. Antifungal compounds can directly function against pathogens. For instance, antifungal metabolites produced by B. pumilus inhibited the mycelial growth of many species of Aspergillus, Penicillium and Fusarium, as well as the production of their respective toxic compounds. The active antifungal compounds were further characterized as either cyclic polypeptides or non-peptidic compounds (Munimbazi and Bullerman 1998). Bacillus sp. IBA 33 showed an inhibitory effect against the growth of Geotrichum candidum, the sour rot disease agent in lemon, due to the secretion of two thermo-resistant proteins (Maldonado et al. 2009).
Accordingly, we tested the effects of the JSCX-1 filtrate on the growth and zoospore germination of $P$. sojae and found that JSCX-1 had negative effects on both parameters (Fig. 3). An antifungal molecule produced by B. licheniformis BC98 had a negative effect on Magnaporthe grisea and exhibited bulbous hyphae, showing a patchy and vacuolated cytoplasm (Tendulkar et al. 2007). Microscopic observations of the effects of the antagonist on $P$. sojae revealed that JSCX-1 induced morphological changes in $P$. sojae (Fig. 3). Thus, the presence of antifungal compounds may be part of the mechanism by which JSCX-1 is able to control Phytophthora rot. Further experimentation is needed to identify what kind of antifungal compounds play this role in JSCX-1.

Antifungal compounds could also indirectly affect the pathogen by inducing plant resistance to defend against pathogen infections (Choudhary and Johri 2009). B. subtilis UMAF6639 secretes lipopeptides and enables plants to prepare against powdery mildew by activating JA- and SA-dependent defense responses (García-Gutiérrez et al. 2013). In the current study, we did not measure whether the JSCX-1 filtrate possesses this ability. However, there is a great possibility that JSCX-1 has this potential. Further experiments should be performed to validity this speculation.

An array of defense responses at both the cellular and molecular levels can be triggered by pathogenic fungi in plants (Jones and Dangl 2006; Boller and He 2009). The oxidative burst and callose deposition are ubiquitous early steps in response to microbial pathogenic attacks (Bolwell et al. 2002; Underwood 2012; Ellinger et al. 2013). The accumulation of hydrogen peroxide is a characteristic early feature of the hypersensitive response (Lamb and Dixon 1997) and callose acts as a physical barrier to slow pathogen invasion (Beffa et al. 1996).

In addition, an accelerated and enhanced accumulation of hydrogen peroxide, and callose deposition, could be conducted using rhizosphere bacteria, especially plant growth promoting rhizobacteria (Conrath et al. 2002; Van Wees et al. 2008), which occur in different plants (Silva et al. 2004; Niu et al. 2011). In the present study, pre-inoculation with JSCX-1 stimulated hydrogen peroxide activity and callose deposition (Fig. 6), inferring that JSCX-1 successfully activated the cellular defenses of plant cells, conferring at least a partially resistance to $P$. sojae. 
The accumulation of PR proteins is an important part of plant defense responses (Van Loon and Van Strien 1999; Van Loon et al. 2006) that has been useful for protecting against fungal pathogens in different plants (Epple et al. 1997; Van Loon and Van Strien 1999). In addition, non-pathogenic bacteria and fungi have the ability to trigger plant basal defenses. Bacillus spp. and their secondary metabolites can act as elicitors to induce or stimulate plant resistance, including ISR (Choudhary and Johri 2009). Bacillus spp. protect plants through ISR and successfully control the disease severity in many plants, such as tobacco, maize, melon and Arabidopsis (Choudhary and Johri 2009; GarcíaGutiérrez et al. 2013; Gond et al. 2015; Huang et al. 2015; Kim et al. 2015). Therefore, it is possible that the BCA isolated in the present study might act as an ISR inducer. The expression level of GmPRla gene was upregulated in our results (Fig. 6), demonstrating that the BCA was able to activate plant basal defense responses, thereby attenuating the Phytophthora infection. These results are similar with studies on the strains of $B$. cereus against DC3000 in Arabidopsis (Niu et al. 2011) and B. amyloliquefaciens against Ralstonia solanacearum in tomato (Tan et al. 2013).

ISR is typically independent of SA and is mostly dependent on the JA- and/or ET-signaling pathways (Verhagen et al. 2004; Pieterse et al. 2009). However, some ISR inducers also appear to activate an SAdependent pathway, indicating that different signaling pathways may operate when ISR is elicited (Ryu et al. 2003; Niu et al. 2011). In the present study, we tested three genes related to the typical signaling pathways and found that the SA-regulated defense-related gene GmPRla had been activated by JSCX-1, the expression of JA-regulated defense-related gene $G m L O X$ was impaired in the control and JSCX-1 treatments (Fig. 6c). However, the ET-regulated defense-related gene GmEREBP did not show any significant difference in leaves treated with $\mathrm{H}_{2} \mathrm{O}$ and JSCX-1 combination with $P$. sojae infection (Fig. 6c). The PR1 gene is mostly used an indicator of systemic acquired resistance (SAR) (Van Loon and Van Strien 1999). This indicates that the disease resistance induced by JSCX-1 may be controlled by an SA-dependent signaling pathway. In many characterized examples, the SA- and JA/ET-signaling pathways mutually interact antagonistically (Koornneef and Pieterse 2008). The bacterial pathogen Erwinia carotovora activated genes expression through JAdependent signaling pathway in Arabidopsis (Norman-
Setterblad et al. 2000). However, by exogenous application of SA, E. carotovora induced gene expression was antagonized (Norman-Setterblad et al. 2000). The results in this study suggest that $P$. sojae-mediated SAR in soybean indeed involves this type of negative crosstalk (Fig. 6c). P. sojae stimulated the expression of SAresponsive gene GmPRla, which lead to the suppression of JA-responsive gene GmLOX (Fig. 6c).

In conclusion, $B$. altitudinis JSCX-1 isolated from a healthy soybean rhizosphere triggered plant resistance against $P$. sojae by an SA-dependent signaling pathway. This indicates that JSCX is a potential biological agent and has promise in enhancing plant disease resistance.

Acknowledgements This work was supported by a Special Fund for Agro-scientific Research in the Public Interest (201303018). We are thankful to Professor Yuanchao Wang for providing the Phytophthora sojae strain. We are appreciated the helpful comments from Professor Isgouhi Kaloshian (University of California, Riverside) and Dr. Dongdong Niu (Nanjing Agricultural University).

\section{Compliance with ethical standards}

Conflict of interest The authors declare that they have no conflict of interest.

Open Access This article is distributed under the terms of the Creative Commons Attribution 4.0 International License (http:// creativecommons.org/licenses/by/4.0/), which permits unrestricted use, distribution, and reproduction in any medium, provided you give appropriate credit to the original author(s) and the source, provide a link to the Creative Commons license, and indicate if changes were made.

\section{References}

Anandhakumar J, Zeller W (2008) Biological control of red stele (Phytophthora fragariae var. fragariae) and crown rot (P. cactorum) disease of strawberry with rhizobacteria. $\mathrm{J}$ Plant Dis Protec 115:7

Anderson TR, Buzzell RI (1992) Inheritance and linkage of the Rps 7 gene for resistance to Phytophthora rot of soybean. Plant Dis 76:958-959

Ayoubi N, Zafari D, Mirabolfathy (2012) Combination of Trichoderma species and Bradyrhizobium japonicum in control of Phytophthora sojae and soybean growth. J Crop Prot 1:67-79

Beffa RS, Hofer RM, Thomas M, Meins F (1996) Decreased susceptibility to viral disease of beta-1,3-glucanase-deficient plants generated by antisense transformation. Plant Cell 8: 1001-1011. doi:10.1105/tpc.8.6.1001 
Benhamou N, Belanger RR (1998) Induction of systemic resistance to Pythium damping-off in cucumber plants by benzothiadiazole: ultrastructure and cytochemistry of the host response. Plant J 14:13-21. doi:10.1046/j.1365-313 X.1998.00088.x

Benhamou N, Kloepper JW, QuadtHallman A, Tuzun S (1996) Induction of defense-related ultrastructural modifications in pea root tissues inoculated with endophytic bacteria. Plant Physiol 112:919-929. doi:10.1104/pp.112.3.919

Bertani G (1951) Studies on lysogenesis I.: the mode of phage liberation by lysogenic Escherichia coli. J Bacteriol 62:293300

Boller T, He SY (2009) Innate immunity in plants: an arms race between pattern recognition receptors in plants and effectors in microbial pathogens. Science 324:742-744. doi:10.1126 /science. 1171647

Bolwell GP, Bindschedler LV, Blee KA, Butt VS, Davies DR, Gardner SL, Gerrish C, Minibayeva F (2002) The apoplastic oxidative burst in response to biotic stress in plants: a threecomponent system. J Exp Bot 53:1367-1376. doi:10.1093 /jexbot/53.372.1367

Chen XH, Koumoutsi A, Scholz R, Eisenreich A, Schneider K, Heinemeyer I, Morgenstern B, Voss B, Hess WR, Reva O, Junge H, Voigt B, Jungblut PR, Vater J, Suessmuth R, Liesegang H, Strittmatter A, Gottschalk G, Borriss R (2007) Comparative analysis of the complete genome sequence of the plant growth-promoting bacterium Bacillus amyloliquefaciens FZB42. Nat Biotechnol 25:1007-1014. doi:10.1038/nbt1325

Choudhary DK, Johri BN (2009) Interactions of Bacillus spp. and plants-with special reference to induced systemic resistance (ISR). Microbiol Res 164:493-513. doi:10.1016/j. micres.2008.08.007

Conrath U, Pieterse CM, Mauch-Mani B (2002) Priming in plantpathogen interactions. Trends Plant Sci 7:210-216. doi:10.1016/S1360-1385(02)02244-6

Dertz EA, Xu JD, Stintzi A, Raymond KN (2006) Bacillibactinmediated iron transport in Bacillus subtilis. J Am Chem Soc 128:22-23. doi:10.1021/ja055898c

Desoignies N, Schramme F, Ongena M, Legrève A (2013) Systemic resistance induced by Bacillus lipopeptides in Beta vulgaris reduces infection by the rhizomania disease vector Polymyxa betae. Mol Plant Pathol 14:416-421. doi:10.1111/mpp. 12008

Dong S, Qutob D, Tedman-Jones J, Kuflu K, Wang Y, Tyler BM, Gijzen M (2009) The Phytophthora sojae avirulence locus $A v r 3 c$ encodes a multi-copy RXLR effector with sequence plymorphisms among pathogen strains. PLoS One 4:e5556. doi:10.1371/journal.pone.0005556

Elbanna K, Elnaggar S, Bakeer A (2014) Characterization of Bacillus altitudinis as a new causative agent of bacterial soft rot. J Phytopathol 162:712-722. doi:10.1111/jph.12250

Ellinger D, Naumann M, Falter C, Zwikowics C, Jamrow T, Manisseri C, Somerville SC, Voigt CA (2013) Elevated early callose deposition results in complete penetration resistance to powdery mildew in Arabidopsis. Plant Physiol 161:14331444. doi:10.1104/pp.112.211011

Epple P, Apel K, Bohlmann H (1997) Overexpression of an endogenous thionin enhances resistance of Arabidopsis against Fusarium oxysporum. Plant Cell 9:509-520. doi:10.1105/tpc.9.4.509
Fiddaman PJ, Rossall S (1994) Effect of substrate on the production of antifungal volatiles from Bacillus subtilis. J Appl Bacteriol 76:395-405

Filonow AB, Lockwood JL (1985) Evaluation of several actinomycetes and the fungus Hyphochytrium catenoides as biocontrol agents for Phytophthora root rot of soybean. Plant Dis 69:1033-1036

Fu HM, Li M, Tan GJ, Wang ZY (2011) Screening and identification of antagonistic strain against Phytophthora sojae. Plant Diseases and Pests 2(9-12):17

Galkiewicz JP, Kellogg CA (2008) Cross-kingdom amplification using bacteria-specific primers: complications for studies of coral microbial ecology. Appl Environ Microbiol 74:78287831. doi:10.1128/aem.01303-08

García-Andrade J, Ramirez V, Flors V, Vera P (2011) Arabidopsis ocp3 mutant reveals a mechanism linking ABA and JA to pathogen-induced callose deposition. Plant J 67:783-794. doi:10.1111/j.1365-313X.2011.04633.x

García-Gutiérrez L, Zeriouh H, Romero D, Cubero J, de Vicente A, Pérez-García A (2013) The antagonistic strain Bacillus subtilis UMAF6639 also confers protection to melon plants against cucurbit powdery mildew by activation of jasmonateand salicylic acid-dependent defence responses. Microb Biotechnol 6:264-274. doi:10.1111/1751-7915.12028

Gond SK, Bergen MS, Torres MS, White JF Jr (2015) Endophytic Bacillus spp. produce antifungal lipopeptides and induce host defence gene expression in maize. Microbiol Res 172:79-87. doi:10.1016/j.micres.2014.11.004

Gopalakrishnan S, Humayun P, Kiran BK, Kannan IGK, Vidya MS, Deepthi K, Rupela O (2011) Evaluation of bacteria isolated from rice rhizosphere for biological control of charcoal rot of sorghum caused by Macrophomina phaseolina (Tassi) Goid. World J Microb Biot 27:1313-1321. doi:10.1007/s11274-010-0579-0

Handelsman J, Raffel S, Mester EH, Wunderlich L, Grau CR (1990) Biological control of damping-off of alfalfa seedlings with Bacillus cereus UW85. Appl Environ Microbiol 56: 713-718

Huang XF, Zhou D, Guo J, Manter DK, Reardon KF, Vivanco JM (2015) Bacillus spp. from rainforest soil promote plant growth under limited nitrogen conditions. J Appl Microbiol 118:672-684. doi:10.1111/jam.12720

Iriti M, Rabotti G, De Ascensa A, Faoro F (2003) Benzothiadiazole-induced resistance modulates ozone tolerance. J Agr Food Chem 51:4308-4314. doi:10.1021 /jf034308w

Ji SH, Paul NC, Deng JX, Kim YS, Yun B-S, Yu SH (2013) Biocontrol activity of Bacillus amyloliquefaciens CNU114001 against fungal plant diseases. Mycobiology 41:234-242. doi:10.5941/MYCO.2013.41.4.234

Jones JD, Dangl JL (2006) The plant immune system. Nature 444: 323-329. doi:10.1038/nature05286

Karimi M, Inze D, Depicker A (2002) GATEWAY((TM)) vectors for Agrobacterium-mediated plant transformation. Trends Plant Sci 7:193-195. doi:10.1016/s1360-1385(02)02251-3

Khabbaz SE, Zhang L, Cáceres LA, Sumarah M, Wang A, Abbasi PA (2015) Characterisation of antagonistic Bacillus and Pseudomonas strains for biocontrol potential and suppression of damping-off and root rot diseases. Ann Appl Biol 166: 456-471. doi:10.1111/aab.12196 
Kim JS, Lee J, Lee C, Woo SY, Kang H, Seo SG, Kim SH (2015) Activation of pathogenesis-related genes by the rhizobacterium, Bacillus sp. JS, which induces systemic resistance in tobacco plants. Plant Pathol J 31:195-201. doi:10.5423/PPJ.NT.11.2014.0122

Kloepper JW, Ryu CM, Zhang S (2004) Induced systemic resistance and promotion of plant growth by Bacillus spp. Phytopathology 94:1259-1266. doi:10.1094 /phyto.2004.94.11.1259

Koornneef A, Pieterse CM (2008) Cross talk in defense signaling. Plant Physiol 146:839-844. doi:10.1104/pp.107.112029

Lamb C, Dixon RA (1997) The oxidative burst in plant disease resistance. Ann Rev Plant Physiol Plant Mol Biol 48:251275. doi:10.1146/annurev.arplant.48.1.251

Li XY, Mao ZC, Wu YX, Ho HH, He YQ (2014) Comprehensive volatile organic compounds profiling of Bacillus species with biocontrol properties by head space solid phase microextraction with gas chromatography-mass spectrometry. Biocontrol Sci Techn 25:132-143. doi:10.1080 /09583157.2014.960809

Livak KJ, Schmittgen TD (2001) Analysis of relative gene expression data using real-time quantitative PCR and the 2(-Delta Delta $C(T)$ ) method. Methods 25:402-408. doi:10.1006 /meth.2001.1262

Lorenzo O, Piqueras R, Sánchez-Serrano JJ, Solano R (2003) ETHYLENE RESPONSE FACTOR1 integrates signals from ethylene and jasmonate pathways in plant defense. Plant Cell 15:165-178. doi:10.1105/tpc.007468

Maksimov IV, Abizgil'dina RR, Sorokan AV, Burkhanova GF (2014) Regulation of peroxidase activity under the influence of signaling molecules and Bacillus subtilis 26D in potato plants infected with Phytophthora infestans. Prikl Biokhim Mikrobiol 50:197-202. doi:10.1134/S0003683814020136

Maldonado MC, Corona J, Gordillo MA, Navarro AR (2009) Isolation and partial characterization of antifungal metabolites produced by Bacillus sp. IBA 33. Curr Microbiol 59: 646-650. doi:10.1007/s00284-009-9489-5

McLeod A, Fry BA, Zuluaga AP, Myers KL, Fry WE (2008) Toward improvements of oomycete transformation protocols. J Eukaryot Microbiol 55:103-109. doi:10.1016/09254439(95)00036-4

Munimbazi C, Bullerman LB (1998) Isolation and partial characterization of antifungal metabolites of Bacillus pumilus. J Appl Microbiol 84:959-968. doi:10.1046/j.13652672.1998.00431.x

Niu DD, Liu HX, Jiang CH, Wang YP, Wang QY, Jin HL, Guo JH (2011) The plant growth-promoting rhizobacterium Bacillus cereus AR156 induces systemic resistance in Arabidopsis thaliana by simultaneously activating salicylate- and jasmonate/ethylene-dependent signaling pathways. Mol Plant Microbe In 24:533-542. doi:10.1094/mpmi-09-100213

Norman-Setterblad C, Vidal S, Palva TE (2000) Interacting signal pathways control defense gene expression in Arabidopsis in response to cell wall-degrading enzymes from Erwinia carotovora. Mol Plant Microbe In 13:430-438. doi:10.1094 /mpmi.2000.13.4.430

Ongena M, Jacques P (2008) Bacillus lipopeptides: versatile weapons for plant disease biocontrol. Trends Microbiol 16: 115-125. doi:10.1016/j.tim.2007.12.009
Osburn RM, Milner JL, Oplinger ES, Smith RS, Handelsman J (1995) Effect of Bacillus cereus UW85 on the yield of soybean at two field sites in Wisconsin. Plant Dis 79:5

Özyilmaz U, Benlioglu K (2013) Enhanced biological control of Phytophthora blight of pepper by biosurfactant-producing Pseudomonas. Plant Pathol J 29:418-426. doi:10.5423/ppj. oa. 11.2012 .0176

Pertot I, Puopolo G, Hosni T, Pedrotti L, Jourdan E, Ongena M (2013) Limited impact of abiotic stress on surfactin production in planta and on disease resistance induced by Bacillus amyloliquefaciens S499 in tomato and bean. FEMS Microbiol Ecol 86:505-519. doi:10.1111/1574-6941.12177

Pieterse CM, Leon-Reyes A, Van der Ent S, Van Wees SC (2009) Networking by small-molecule hormones in plant immunity. Nat Chem Biol 5:308-316. doi:10.1038/nchembio.164

Qiao YL, Liu L, Xiong Q, Flores C, Wong J, Shi JX, Wang XB, Liu XG, Xiang QJ, Jiang SS, Zhang FC, Wang YC, Judelson HS, Chen XM, Ma WB (2013) Oomycete pathogens encode RNA silencing suppressors. Nat Genet 45:330-335. doi:10.1038/ng. 2525

Reasoner DJ, Geldreich EE (1985) A new medium for the enumeration and subculture of bacteria from potable water. Appl Environ Microbiol 49:1-7

Ryu CM, Farag MA, Hu CH, Reddy MS, Wei HX, Pare PW, Kloepper JW (2003) Bacterial volatiles promote growth in Arabidopsis. P Natl Acad Sci USA 100:4927-4932. doi:10.1073/pnas. 0730845100

Shan WX, Cao M, Dan LU, Tyler BM (2004) The Avrlb locus of Phytophthora sojae encodes an elicitor and a regulator required for avirulence on soybean plants carrying resistance gene Rps Ib. Mol Plant Microbe In 17:394-403. doi:10.1094 /mpmi.2004.17.4.394

Silva HSA, Romeiro RS, Carrer R, Pereira JLA, Mizubuti ESG, Mounteer A (2004) Induction of systemic resistance by Bacillus cereus against tomato foliar diseases under field conditions. J Phytopathol 152:371-375. doi:10.1111/j.14390434.2004.00853.x

Song TQ, Kale SD, Arredondo FD, Shen DY, Su LM, Liu L, Wu YR, Wang YC, Dou DL, Tyler BM (2013) Two RxLR avirulence genes in Phytophthora sojae determine soybean Rps 1 -mediated disease resistance. Mol Plant Microbe In 26: 711-720. doi:10.1094/mpmi-12-12-0289-r

Sunar K, Dey P, Chakraborty U, Chakraborty B (2015) Biocontrol efficacy and plant growth promoting activity of Bacillus altitudinis isolated from Darjeeling hills India. J Basic Microb 55:91-104. doi:10.1002/jobm.201300227

Tamura K, Peterson D, Peterson N, Stecher G, Nei M, Kumar S (2011) MEGA5: molecular evolutionary genetics analysis uing maximum likelihood, evolutionary distance, and maximum parsimony methods. Mol Biol Evol 28:2731-2739. doi:10.1093/molbev/msr121

Tan S, Dong Y, Liao H, Huang J, Song S, Xu Y, Shen Q (2013) Antagonistic bacterium Bacillus amyloliquefaciens induces resistance and controls the bacterial wilt of tomato. Pest Manag Sci 69:1245-1252. doi:10.1002/ps.3491

Tendulkar SR, Saikumari YK, Patel V, Raghotama S, Munshi TK, Balaram P, Chattoo BB (2007) Isolation, purification and characterization of an antifungal molecule produced by Bacillus licheniformis $\mathrm{BC} 98$, and its effect on phytopathogen Magnaporthe grisea. J Appl Microbiol 103:2331-2339. doi:10.1111/j.1365-2672.2007.03501.x 
Thimon L, Peypoux F, Magetdana R, Roux B, Michel G (1992) Interactions of bioactive lipopeptides, iturin-a and surfactin from Bacillus subtilis. Biotechnol Appl Bioc 16:144-151

Thordal-Christensen H, Zhang ZG, Wei YD, Collinge DB (1997) Subcellular localization of $\mathrm{H}_{2} \mathrm{O}_{2}$ in plants. $\mathrm{H}_{2} \mathrm{O}_{2}$ accumulation in papillae and hypersensitive response during the barley-powdery mildew interaction. Plant J 11:1187-1194. doi:10.1046/j.1365-313X.1997.11061187.x

Tyler BM, Forster H, Coffey MD (1995) Inheritance of avirulence factors and restriction-fragment-length-polymorphism markers in outcrosses of the oomycete Phytophthora sojae. Mol Plant Microbe In 8:515-523. doi:10.1094/mpmi-8-0515

Underwood W (2012) The plant cell wall: a dynamic barrier against phogen invasion. Front Plant Sci 3:85. doi:10.3389 /fpls.2012.00085

Utkhede RS (1984) Antagonism of isolates of Bacillus subtilis to Phytophthora cactorum. Can J Bot 62:1032-1035. doi:10.1139/b84-142

Van Loon L, Bakker P (2005) Induced systemic resistance as a mechanism of disease suppression by rhizobacteria. In: Siddiqui ZA (ed) PGPR: biocontrol and biofertilization. Springer, The Netherlands, pp 39-66. doi:10.1007/1-40204152-7_2

Van Loon LC $\bar{C}$, Van Strien EA (1999) The families of pathogenesisrelated proteins, their activities, and comparative analysis of PR-1 type proteins. Physiol Mol Plant Pathol 55:85-97. doi:10.1006/pmpp.1999.0213

Van Loon LC, Rep M, Pieterse CMJ (2006) Significance of inducible defense-related proteins in infected plants. Ann Rev Phytopathol 44:135-162. doi:10.1146/annurev. phyto.44.070505.143425

Van Wees SC, Van der Ent S, Pieterse CM (2008) Plant immune responses triggered by beneficial microbes. Curr Opin Plant Biol 11:443-448. doi:10.1016/j.pbi.2008.05.005

Vanittanakom N, Loeffler W, Koch U, Jung G (1986) Fengycin- a novel antifungal lipopeptide antibiotic produced by Bacillus subtilis F-29-3. J Antibio 39:888-901. doi:10.7164 /antibiotics.39.888

Verhagen BW, Glazebrook J, Zhu T, Chang HS, van Loon LC, Pieterse CM (2004) The transcriptome of rhizobacteriainduced systemic resistance in arabidopsis. Mol Plant Microbe In 17:895-908. doi:10.1094/mpmi.2004.17.8.895

Wang C, Zien CA, Afitlhile M, Welti R, Hildebrand DF, Wang X (2000) Involvement of phospholipase D in wound-induced accumulation of jasmonic acid in arabidopsis. Plant Cell 12: 2237-2246. doi:10.1105/tpc.12.11.2237

Xiao K, Kinkel LL, Samac DA (2002) Biological control of Phytophthora root rots on alfalfa and soybean with Streptomyces. Biol Control 23:285-295. doi:10.1006 /bcon.2001.1015

Yamamoto S, Harayama S (1995) PCR amplification and direct sequencing of gyrb genes with universal primers and their application to the detection and taxonomic analysis of Pseudomonas putida strains. Appl Environ Microbiol 61: 1104-1109

Yedidia I, Shoresh M, Kerem Z, Benhamou N, Kapulnik Y, Chet I (2003) Concomitant induction of systemic resistance to Pseudomonas spingae pv. lachrymans in cucumber by Trichoderma asperellum (T-203) and accumulation of phytoalexins. Appl Environ Microbiol 69:7343-7353. doi:10.1128/aem.69.12.7343-7353.2003

Yuan J, Raza W, Shen Q, Huang Q (2012) Antifungal activity of Bacillus amyloliquefaciens NJN-6 volatile compounds against Fusarium oxysporum f. Sp. cubense. Appl Environ Microbiol 78:5942-5944. doi:10.1128/aem.01357-12

Zhang M, Meng Y, Wang Q, Liu D, Quan J, Hardham AR, Shan W (2012) PnPMA1, an atypical plasma membrane H(+)ATPase, is required for zoospore development in Phytophthora parasitica. Fungal Biol-UK 116:1013-1023. doi:10.1016/j.funbio.2012.07.006 